\title{
PENYULUHAN GIZI SEIMBANG KELUARGA MENUJU MASYARAKAT YANG SEHAT DAN CERDAS
}

\author{
Handa Muliasari1 ${ }^{\star}$, Candra Dwipayana Hamdin¹, Raisya Hasina ${ }^{1}$, dan Muhsinul Ihsan² \\ 1)Program Studi Farmasi, Fakultas Kedokteran, Universitas Mataram \\ 2)Jurusan Biologi Fakultas Tarbiyah dan keguruan UIN Mataram \\ *Email: handamuliasari@unram.ac.id
}

\begin{abstract}
Abstrak - Gizi seimbang merupakan aneka ragam bahan pangan yang mengandung unsur-unsur zat gizi yang diperlukan oleh tubuh, baik kualitas (fungsinya) maupun kuantitas (jumlahnya). Kabupaten Lombok Tengah merupakan salah satu daerah di Nusa Tenggara Barat yang memiliki masalah gizi yang signifikan yaitu berada pada kategori gizi kurang dan buruk, serta cenderung pertumbuhan terganggu akut/kronis. Kegiatan pengabdian berupa penyuluhan gizi seimbang keluarga ini bertujuan untuk menciptakan masyarakat yang sehat dan cerdas dengan pemenuhan gizi seimbang. Untuk mengatasi permasalahan rendahnya status gizi masyarakat, penting untuk dilakukan penyuluhan gizi seimbang keluarga untuk masyarakat khususnya di Desa Bonder Kecamatan Praya Barat Kabupaten Lombok Tengah. Penyuluhan gizi yang dilakukan di Dusun Ketawang, Desa Bonder dihadiri oleh 93 warga berbagai usia. Peserta sangat tertarik dengan materi penyuluhan gizi seimbang keluarga karena disajikan sederhana dan menarik oleh ahli gizi dari daerah setempat. Berdasarkan hasil diskusi dan tanya jawab, disimpulkan bahwa masyarakat Dusun Ketawang telah menerima informasi gizi seimbang keluarga dengan baik.
\end{abstract}

Kata Kunci: Penyuluhan, gizi seimbang, Farmasi, Desa Bondir, Praya Barat, Lombok Tengah

\section{LATAR BELAKANG}

Gizi seimbang merupakan aneka ragam bahan pangan yang mengandung unsur-unsur zat gizi yang diperlukan oleh tubuh, baik kualitas (fungsinya), maupun kuantitas (jumlahnya). Saat ini, Indonesia mengalami masalah gizi ganda, bukan hanya masalah kekurangan gizi yang dihadapi Indonesia, kelebihan gizi pun kini menjadi momok yang tengah diperangi pemerintah. Sebab, keduanya dapat berakibat buruk terhadap kesehatan dan kualitas hidup manusia (Kemenkes RI, 2014).

Data Riskesdas 2010 menyebutkan, jumlah persentase status gizi kategori kurus dirinci sebagai berikut : pada balita 13,3\%, dan anak sekolah usia 6 - 12 tahun 12,2\%. Sementara itu jumlah persentase masyarakat Indonesia yang gemuk dirinci sebagai berikut : pada balita $14 \%$, pada anak usia 6 - 12 tahun sebanyak $9,2 \%$, pada anak usia 13 - 15 tahun 2,5\%, anak usia 16 - 18 tahun $1,4 \%$, dan dewasa lebih dari 18 tahun sebanyak $21,7 \%$. Jika dulu masyarakat golongan kelas menengah yang identik berbadan subur, kini di masalah peralihan, kelebihan berat badan justru diderita masyarakat dengan tingkat ekonomi rendah. Kedua masalah tersebut muncul karena pola makan yang tidak seimbang.

Kekurangan gizi ditandai dengan lambatnya pertumbuhan tubuh (terutama pada anak), daya tahan tubuh rendah, kurangnya tingkat inteligensia, dan produktivitas yang rendah. Kelebihan gizi sebaliknya, ditandai dengan kelebihan berat badan, besarnya risiko kemunculan berbagai penyakit kronis degeneratif seperti diabetes, tekanan darah tinggi, dan penyakit jantung. Masalah dalam pemberian makan anak di rentang usia 3 - 5 tahun di antaranya anak tidak suka sayuran, pilih-pilih makanan, dan menyukai junk food (Naristasari, 2015).

Kabupaten Lombok Tengah merupakan salah satu daerah di Nusa Tenggara Barat yang memiliki masalah gizi dengan status gizi kurang dan buruk. Status gizi umumnya diukur pada balita dengan indikator : berat badan menurut umur (BB/U), tinggi badan menurut umur (TB/U), berat badan menurut tinggi badan (BB/TB), gabungan indikator TB/U dan BB/TB. Pemantauan status gizi (PSG) yang dilakukan di Kabupaten Lombok Tengah pada tahun 2015 dari berbagai indikator di atas dapat disimpulkan bahwa kondisi gizi di Lombok Tengah berada pada posisi 3 (cenderung gangguan pertumbuhan akut/kronis) (Dikes Kab. Lombok Tengah, 2015). 
Permasalahan tersebut dapat diatasi dengan menerapkan pola gizi berimbang sesuai dengan pedoman gizi seimbang (PUGS) yang dikeluarkan oleh Direktorat gizi depkes pada tahun 1995. Tujuan PUGS merupakan alat untuk memberikan penyuluhan pangan dan gizi kepada masyarakat luas, dalam rangka memasyarakatkan gizi seimbang (Almatsier, 2004).

\section{METODE PELAKSANAAN}

Pelaksanaan kegiatan penyuluhan gizi seimbang keluarga dilakukan dalam kegiatan yang melibatkan dosen di lingkungan Program Studi Farmasi Universitas Mataram dan ahli gizi di NTB serta melibatkan warga masyarakat Desa Bondir Kecamatan Praya Barat Kabupaten Lombok Tengah. Pendekatan yang digunakan dalam kegiatan penyuluhan berupa pola penyelesaian masalah dilanjutkan dengan diskusi dan tanya jawab mengenai gizi seimbang keluarga.

\section{HASIL DAN PEMBAHASAN}

Penyuluhan gizi seimbang keluarga berhasil dilakukan di Dusun Ketawang, Desa Bonder, Kecamatan Praya Barat, Lombok Tengah dengan jumlah peserta 93 orang dengan usia yang beragam. Antusisme warga untuk mengikuti kegiatan sangat terlihat sejak mulai dilakukan persiapan di lokasi kegiatan yaitu halaman PAUD di Dusun Ketawang. Partisipasi warga dimulai sejak dilakukannya persiapan dimana warga ikut terlibat membantu persiapan kegiatan. Selain itu ditunjukkan dengan jumlah peserta yang melebihi target 50 orang.

Pemberian materi dimulai dengan tanya jawab seputar materi yang akan disampaikan sebagai bentuk pretest yang diberikan untuk mengukur pengetahuan awal peserta. Selain itu, untuk menambah rasa keingintahuan peserta terkait dengan materi yang akan disampaikan. Bedasarkan pertanyaan-pertanyaan yang diberikan dan jawaban yang disampaikan oleh warga saat kegiatan berlangsung, sangat terlihat keterbatasan pengetahuan dasar tentang gizi seimbang di masyarakat. Sehingga dirasa tepat jika kegiatan dilaksanakan pada lokasi tersebut.
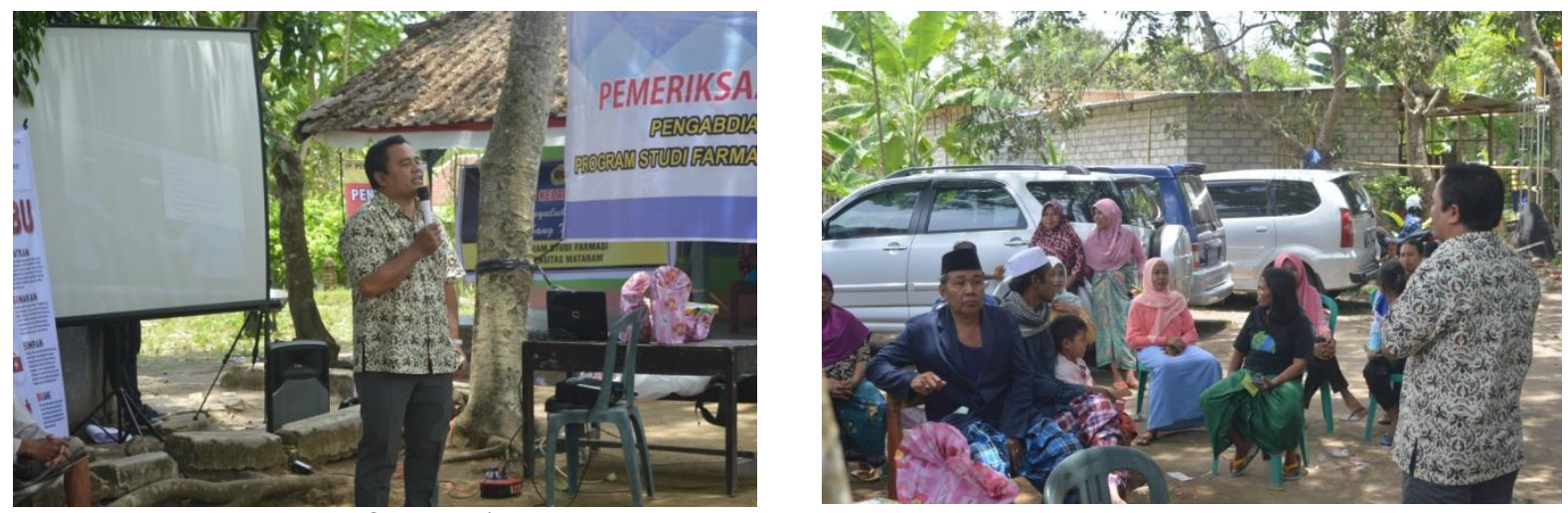

Gambar. 1. Penyampaian materi gizi seimbang keluarga oleh ahli gizi 

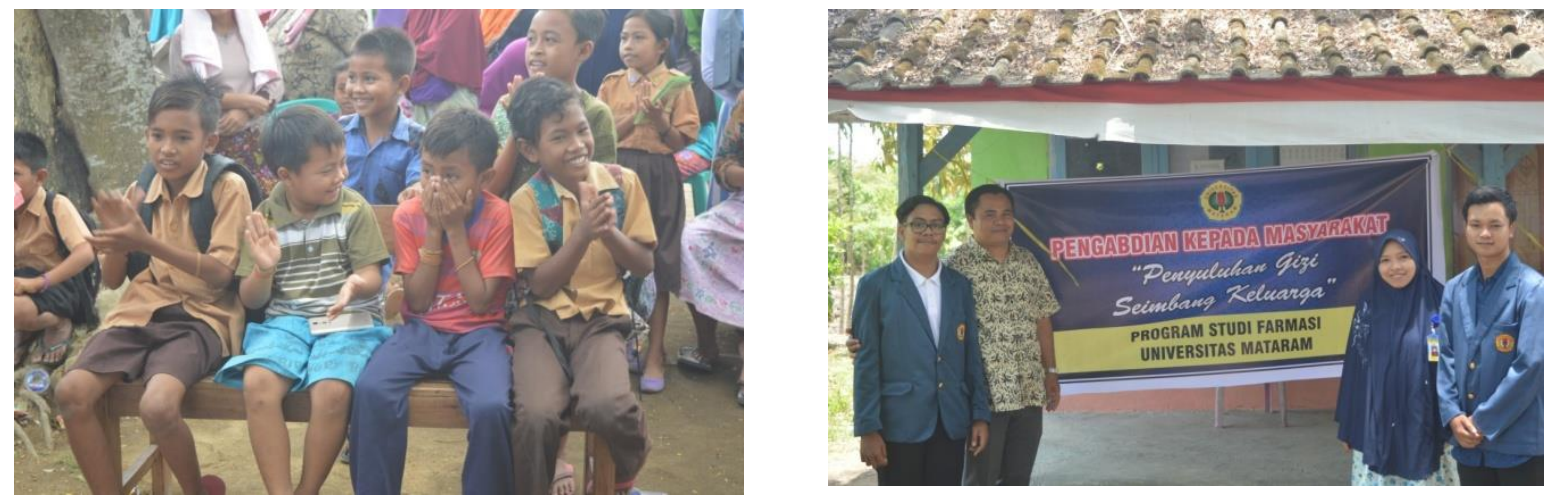

Gambar.2. Anak-anak ikut meramaikan kegiatan penyuluhan (kiri); narasumber dan panitia (kanan)

Inti materi yang diberikan oleh narasumber ahli gizi yaitu pemenuhan gizi seimbang pada anak balita sangat penting untuk dipahami para orang tua karena mengingat usia anak balita merupakan masa emas yang akan menentukan proses pertumbuhan dan perkembangan pada masa mendatang. Salah satu faktor yang mempengaruhi status gizi anak balita adalah pengetahuan dan sikap ibu dalam memilih dan memberikan makanan untuk memperoleh kebutuhan gizi yang seimbang untuk anak balita. Ibu sebaiknya memahami bahwa pola pemberian makanan secara seimbang pada usia dini akan berpengaruh terhadap selera makan anak selanjutnya, sehingga pengenalan kepada makanan yang beraneka ragam pada periode ini menjadi sangat penting secara bertahap. Anak balita usia 6 bulan mulai diberikan sayuran dan buahbuahan, lauk pauk sumber protein hewani dan nabati, serta makanan pokok sebagai sumber kalori. Demikian pula jumlahnya ditambahkan secara bertahap dalam jumlah yang tidah berlebihan dan dalam proporsi yang juga seimbang.

Faktor yang tidak kalah penting untuk diperhatikan adalah kebersihan dan kandungan bahan berbahaya dalam jajanan anak-anak. Sangat penting untuk dipahami bahwa makanan yang tidak higienis dan mengandung bahan tambahan makanan yang berbahaya akan memberikan efek buruk bagi anak-anak sebagai generasi penerus bangsa.

Oleh karena itu, para orang tua harus mengawasi dan memberikan makanan yang sehat dengan gizi seimbang. Makanan tersebut tidak perlu mahal, cukup dengan sayur dan buah yang ditanam di sekitar rumah.

Setelah seluruh materi diberikan, selanjutnya dilakukan evaluasi secara acak kepada peserta. Berdasarkan jawaban yang disampaikan oleh peserta, disimpulkan peserta dapat menerima materi yang telah disampaikan. Selain itu evaluasi juga dilakukan dengan kuis-kuis yang diberikan pada setiap selingan kegiatan. Antusiasme peserta dalam menjawab dan jawaban yang diberikan menunjukkan peserta menguasai sebagian besar materi yang disampaikan. Hal ini menjadi salah satu indikator ketercapaian tujuan kegiatan penyuluhan gizi seimbang keluarga.

\section{KESIMPULAN DAN SARAN}

Berdasarkan hasil kegiatan penyuluhan dapat disimpulkan bahwa peserta penyuluhan gizi di Dusun Ketawang, Desa Bonder, Kecamatan Praya Barat, Lombok Tengah sejumlah 93 orang telah menerima informasi gizi seimbang keluarga dengan baik. 


\section{DAFTAR PUSTAKA}

Almatsier, 2004. Prinsip Dasar IImu Gizi. Penerbit PT. Gramedia pustaka Utama, Jakarta.

Dinas kesehatan Kabupaten Lombok Tengah, 2015, Profil kesehatan tahun 2015, Dinas Kesehatan Kabupaten Lombok Tengah.

KEMENKES RI, 2014, Laporan Nasional Riset Kesehatan Dasar (Riskesdas) Tahun 2014, Badan Penelitian dan Pengembangan Kesehatan DEPKES RI

Naristasari, A.A. 2015. Hubungan status gizi dengan kejadian anemia pada siswi kelas XI di tiga SMA kota Yogyakarta tahun 2015. Naskah Publikasi Program Studi Bidan Pendidik Jenjang Diploma IV Sekolah Tinggi IImu Kesehatan 'Aisyiyah Yogyakarta Tahun 2015. 